\section{Estimation Of Runoff And Erosion Rates Using Agwa - Kineros2 Model: Application To A Mediterranean Watershed}

\section{El Harche Sanae,}

Department of Natural Resources and Environment Hassan II Institute of Agronomy and Veterinary

Medicine, Rabat, Morocco

\section{Chikhaoui Mohamed,}

Department of Natural Resources and Environment Hassan II Institute of Agronomy and Veterinary Medicine, Rabat, Morocco

\section{Naimi Mustapha,}

Department of Natural Resources and Environment Hassan II Institute of Agronomy and Veterinary Medicine, Rabat, Morocco

Submitted: 23 October 2020

Accepted: 14 December 2020

Published: 31 December 2020

Corresponding author:

El Harche Sanae

\section{DOI: 10.19044/esj.2020.v16n36p193 \\ (c) Copyright 2020 El Harche S, Distributed under Creative Commons BY-NC-ND 4.0 OPEN ACCES}

\section{Cite as:}

El Harche S, Chikhaoui M. Naimi M.(2020). Estimation Of Runoff And Erosion Rates Using Agwa - Kineros2 Model: Application To A Mediterranean Watershed European Scientific Journal, ESJ, 16 (36), 1.

https://doi.org/10.19044/esj.2020.v16n36p193

\begin{abstract}
The Mediterranean area is classified as a region highly threatened by water erosion, which depends largely on climatic aggressiveness, erodible soils, sparse vegetation, and irrational human activity. Tleta watershed belongs to a young mountain ridge (Rif), readily erodible and highly vulnerable to water erosion. To assess the extent of this phenomenon, AGWA tool coupled with KINEROS2 (K2) model was used to predict the specific degradation and the hydrological functioning of the studied watershed. The data required consisted of topography, land use, soil type, and precipitation. The model simulations will make it possible to estimate the sediment load deposited at the Ibn Batouta dam, which results from upstream erosion. The evaluation criteria for the predictive skill of K2 model when comparing observed and simulated data are the coefficient of determination (R2) and the Nash-Sutcliffe model efficiency coefficient (NSE). These two coefficients are respectively $\left(\mathrm{R}^{2}=0.99\right.$, NSE $\left.=0.71\right)$ and $\left(\mathrm{R}^{2}=0.99\right.$, NSE $\left.=0.72\right)$ for runoff and sediments yield for calibration. For the validation process, these two coefficients are $\left(\mathrm{R}^{2}=0.99\right.$ and NSE $\left.=0.98\right)$ for runoff and $\left(\mathrm{R}^{2}=0.99\right.$ and $\left.\mathrm{NSE}=0.97\right)$ for sediments yield. This allows us to conclude that the predictive accuracy of the model is promising.
\end{abstract}

Subject: Hydrology

Keywords: Runoff, Modeling, Water Erosion, KINEROS2, AGWA, Tleta Watershed 


\section{Introduction}

Water supply systems in Morocco are threatened by the reduction of quantities and the degradation of qualities due to climate change and overexploitation of the resources (Heusch, 1973; Lahlou, 1994; Lammadalena, 2010). The rainfall intensity and its irregularity also favor soil erosion and aggravate the consequences on soil productivity (Pepin et al., 2012). The decrease in vegetation cover reduces surface roughness and hence exposes the soil to water erosion (Canfield \& Goodrich, 2005). Soil erosion, with annual soil losses of 2000-6000 t/km2/year (Chikhaoui \& Naimi, 2011), is a major environmental and economic matter that jeopardizes the sustainability of dam reservoir and agricultural activities. The Tleta watershed evolves with the construction of the new city of Cherrafat, the development of fruit tree orchards, and the transformation of matorral into cultivated lands. Water resources are limited to surface water (Sabir et al., 2004) and their mobilization is mainly ensured by the Ibn Batouta dam. This reservoir, located at the outlet of the basin, supplies water for the city of Tangiers. Nevertheless, its continuous siltation as a consequence of soil water erosion may hinder the availability of water in the future (Sabir et al., 2019).

Models can be a time- and cost-efficient method for managing water resources and developing predictive scenarios by extending existing knowledge. Once validated using observed data, a model has the potential to predict outcomes and to evaluate scenarios for best management practices (Morrison et al., 2013). The AGWA tool was developed by Agricultural Research Service, US Environmental Protection Agency, and the University of Arizona. AGWA with Arc View interface is an open-source (Miller et al., 2002) parameters KINEROS2 model. This is a physical event model which describes the processes of dynamic infiltration, surface runoff, interception and erosion in watersheds, and is characterized primarily by overland flow (Smith et al., 1995). The model is widely used in semi-arid areas and provides a good understanding of the response of watersheds to land shift and management. KINEROS was first deployed by Woolhiser et al. (1970), and its evolution and improvement have been carried out over many years ago (Woolhiser et al., 1990; Goodrich et al., 2002; Smith et al., 1995;). KINEROS2, the newest version was used as a tool for modeling flows and solid fluxes in several studies (Mansouri et al., 2001; Augusto et al., 2002; Lajili, 2004; Bissiri et al., 2004; Jaoued et al., 2005; Al-Qurashi et al., 2008; Afef, 2014; Laetitia, 2016;). However, this model relies heavily on subdividing watersheds into response units and assigning appropriate parameters. The AGWA tool automates this step to facilitates the parameterization of KINEROS2 (Semmens et al., 2008).

The singular feature of AGWA is the possibility to use internationally available spatial data sets to delineate the watershed, subdivide it into model 
elements, and derive all necessary parameter inputs for each model element (Kepner et al., 2008). Above all, AGWA tool was developed to ensure that parameterization procedures are simple, straightforward, transparent, and reproducible. This means that it should be compatible with available GIS data layers and useful for the assessment of future scenarios at multiple scales (Semmens et al., 2008). It also allows spatial visualization and comparison between model outputs, and thus permits the assessment of hydrological impacts associated with landscape change. AGWA is also designed to identify risk areas in watersheds that are particularly vulnerable to degradation and where restoration can be effective (Kepner et al., 2004; Kepner et al., 2008; Semmens et al., 2008).

The main objectives of this study include the following: (1) To calibrate and validate AGWA tool in the Tleta watershed using observed data from the Loukkos Hydraulic Basin Agency (ABHL); (2) To assess the hydrology dynamic and water erosion process; and (3) To investigate the utility of KINEROS2 model in helping the decision makers in their water management and soil conservation planning process.

\section{Material and Methods}

\section{Study Area}

The Tleta watershed (17700 ha), located in the western Rif north of Morocco, is subjected to dual moderating influence. The climate is subhumid with mild winters and hot summers, and it is characterized by a dry period (May-September) and a wet period (October-March) (Hammouda, 2010). The Ibn Batouta dam at the outlet of Tleta watershed was built in 1977 with an initial capacity of $45 \mathrm{Mm}^{3}$. However, as a result of the annual silting, the capacity is now reduced to $30 \mathrm{Mm}^{3}$, representing $1 \%$ of the dam volume (ABHL, 2013; ALMIRA Project).

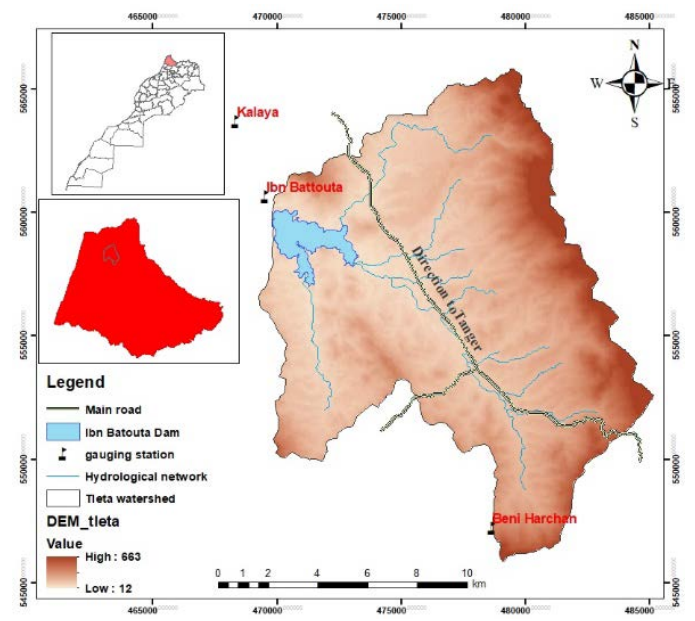

Figure 1. Geographic location of Tleta watershed 


\section{AGWA-K2 Interface \\ Description of Models Used}

AGWA is a Geographic Information System (GIS) interface designed to facilitate the management and analysis of water quantity and quality in watersheds (Miller et al., 2007). This tool is intended to provide qualitative estimates of runoff and erosion in relation to landscape changes. The data required include elevation, land use and soil type, precipitation, soil moisture, and water quality (Goodrich et al., 2012). The input parameters are derived directly from this data using the optimized look-up tables supplied with the tool. AGWA is an extension for ArcView3.x (ESRI), which is freely downloadable from the Internet (http://www.tucson.ars.ag.gov/agwa/). It is also associated with a forum of users and developers to improve the model performance. AGWA initially uses primary data (coming directly from GIS), which illustrates the topography and the soil of the watershed. In a second step, this primary data is used in conjunction with a series of correspondence tables, built from literature and field experiments. This is done in order to deduce the secondary data (hydrodynamic parameters) necessary for modeling hydrological processes (Levick et al., 2009).

KINEROS2 is an event physical model that describes the processes of surface runoff, interception, dynamic infiltration, and erosion of agricultural, rangeland, and urban watersheds. K2, a largely updated version of KINEROS, which is now integrated into AGWA, has been described by Smith et al. (1995) and its documentation was published by Woolhiser et al. (1990). This new version, named KINEROS2, is used to calculate rainfall excess for surface runoff by excess infiltration. Following the first version, some new features have been added to make the structure of the model more robust for wider applications. A watershed is represented as a series of flow plans and cascading channels by which the processes of infiltration, interception, retention, erosion, sediment flow, transport, and deposition are explicitly addressed (Goodrich, et al., 2011). K2 allows the description of processes of interception, infiltration, runoff or erosion as a function of topography, precipitation, soil, and cover properties (Semmens et al., 2008).

\section{Watershed Delineation}

The first step to conduct watershed analysis and assessment is the delineation of its limits. In the second step, the watershed is subdivided into model elements. A specified value is defined as a threshold of the contributing area to determine the location and length of flow channels. Watercourses are used to define surface flow paths, identify mountain and side planes, and thus control the complexity of the landscape representation (Goodrich et al., 2012). 


\section{Watershed Discretization}

The level of the geometric complexity of the discretization of a watershed is highly dependent on the number of CSAs (Contributing Source Area) (Thieken et al., 1999). This is because the more the CSA produces elements, the more the drainage network is developed. Ideally, the complexity of the simulated watershed corresponds to the heterogeneity of the watershed and the spatial resolution of simulated processes ( Lane et al., 1975; Kalin et al., 2003; Canfield \& Goodrich, 2006). The optimal size of a CSA depends on the case study, but a value of less than $2.5 \%$ of the total watershed area is generally selected (Helmlinger et al., 1993). The objective of dividing the watershed into plans and channels is to preserve the integrity of the spatial variation of topography, soil type, vegetation cover, and precipitation. K2 deals dynamically with infiltration by taking into account the relief, the hydrographic network, land use, and geology. The numbers represent the AGWA-imposed scheme used to ensure hydrological connectivity from the watershed boundaries to the outlet. The hydrological modeling in AGWA is sensitive to the shape and size of the channels through which water is conveyed (Miller et al., 2002). Specification of the channel geometry is crucial for both the efficient delivery of water and the estimation of channel scour and deposition processes. As this information cannot be inferred from a typical DEM, AGWA uses empirical hydraulic-geometric relationships to estimate the channel geometry based on the contribution area for the top and bottom of each section of the canal system. Once the correct watershed boundary has been determined, the watershed is subdivided into model elements.

\section{Parametrization}

Parametrization consists of integrating two input files, which are necessary for the application of KINEROS2 model, namely: a hydrologic parameters file and an accumulated rainfall file.

A "PARAMETERS" file contains the physical, hydrological, and flow parameters for all the elements of the watershed (channels and plans), which describe the properties of infiltration. The parameterization of the watershed elements is characterized by its hydraulic geometry, flow length and unique land cover, and soil properties. The flow is controlled by the gradient, slope length, and soil hydraulic resistance parameters. The calculation of Hortonian flow rates requires Manning or Chezy parameters, which are determined in this step automatically based on experimental measurements (Woolhiser et al., 1990).

A "PRECIPITATION" file consists of writing the input files and executing the model. AGWA browses in a loop through the discretization attributes of the selected watershed and creates the text files used to run the model. This file contains the parameters of rainfall event, which is recorded by 
the rain gauge at the Ibn Batouta dam. Each rainfall event is represented by its frequency and duration for a fixed time step of 5 minutes. The elements delimited by AGWA are represented in K2 by a set of parameter values assumed to be uniform throughout. When soil and canopy parameters are variable within the same element, AGWA uses a weighting procedure to estimate the mean value for each parameter (Miller et al., 2002). The FAO database is characterized by a set of codes to which hydrodynamic properties are attached. Using different field expertise, textural properties can be directly linked to each landscape unit. The correspondence of these textures with those assigned for each FAO class allows the linking of code to a unit. In order to complete the parameterization of the various elements of the watershed, the vegetation cover layer must be taken into account. The vegetation will particularly introduce the parameters of soil roughness, whose minimum value is fixed by $\mathrm{K} 2$ at 0.001 and interception. It will also contribute to modify the hydraulic conductivity at saturation, which is previously defined by the soil layer (Levick et al., 2009).

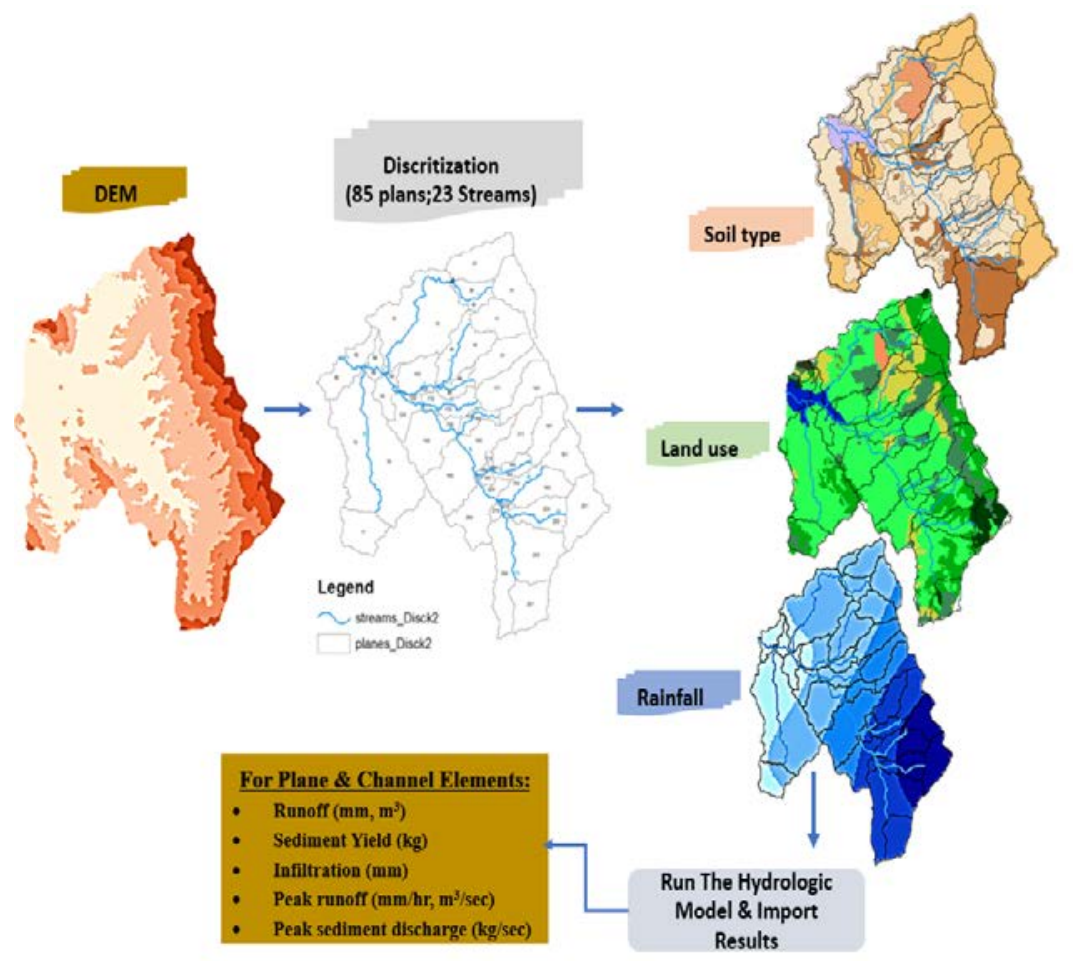

Figure 2. Conceptual design of AGWA modified from (Goodrich et al., 2011) and CSAs for the Tleta watershed

\section{Input Data}

K2 needs four sets of input data to operate: DEM, soil map, land cover map (necessary to describe the watershed in terms of hydrological and 
geometric parameters), and precipitation. The input data used in this study are summarized in Table 1.

Table 1. Input data, its resolution, and source used in K2 model simulations

\begin{tabular}{|c|c|c|}
\hline Type & Source & Description \\
\hline DEM & SPOT $(20 \mathrm{~m})$ & DEM \\
\hline Soil & Inypsa $(1987)$ & Soil survey $(1 / 50000)$ \\
\hline Land cover & Landsat $(30 \mathrm{~m})$ & Image processing \\
\hline Rainfall & ABHL & Daily rainfall $(1998-2018)$ \\
\hline
\end{tabular}

\section{Soil Characteristics}

The soil characteristics of the watershed have been analyzed from previous studies (Ezzine et al., 2011; Inypsa, 1987). Soils are divided into five categories based on texture: Clay, Clay loam, sandy Clay loam, Sandy Loam, and Silty Clay.

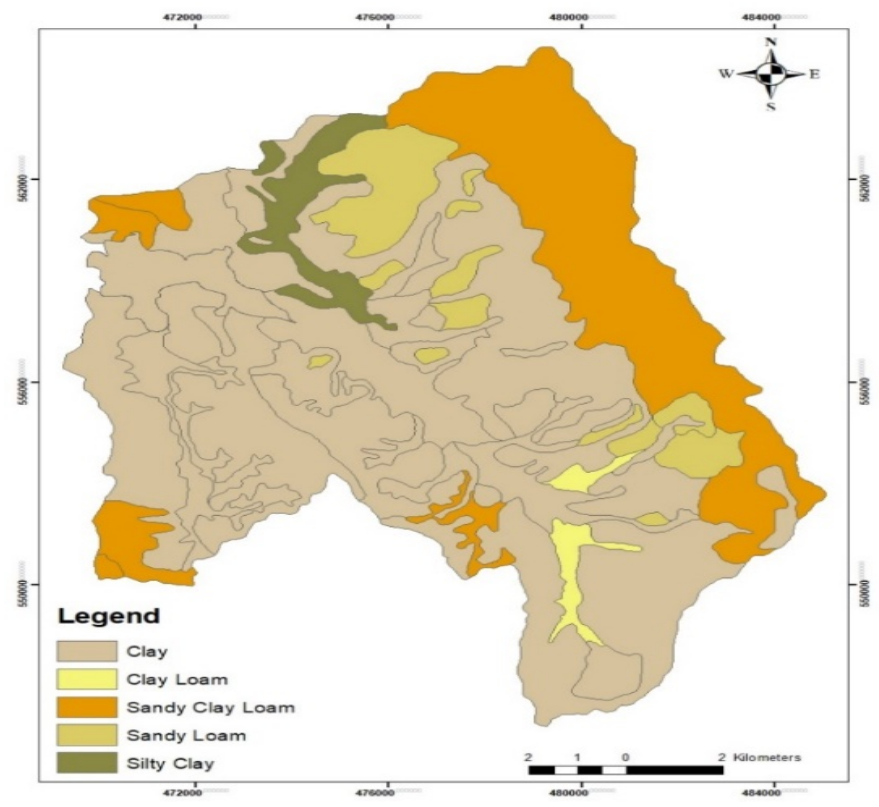

Figure 3.Map of soil texture

\section{Land Cover Characteristics}

Land cover map was derived from image processing of Landsat image (2009). It is worthy to mention that over the period (1987 - 2002), the basin has undergone a reduction in cereal planting areas in favor of olive plantations. Water erosion, exacerbated by the geomorphological settings of the basin, is increased by land abandonment and intense land use (Hammouda, 2010). 


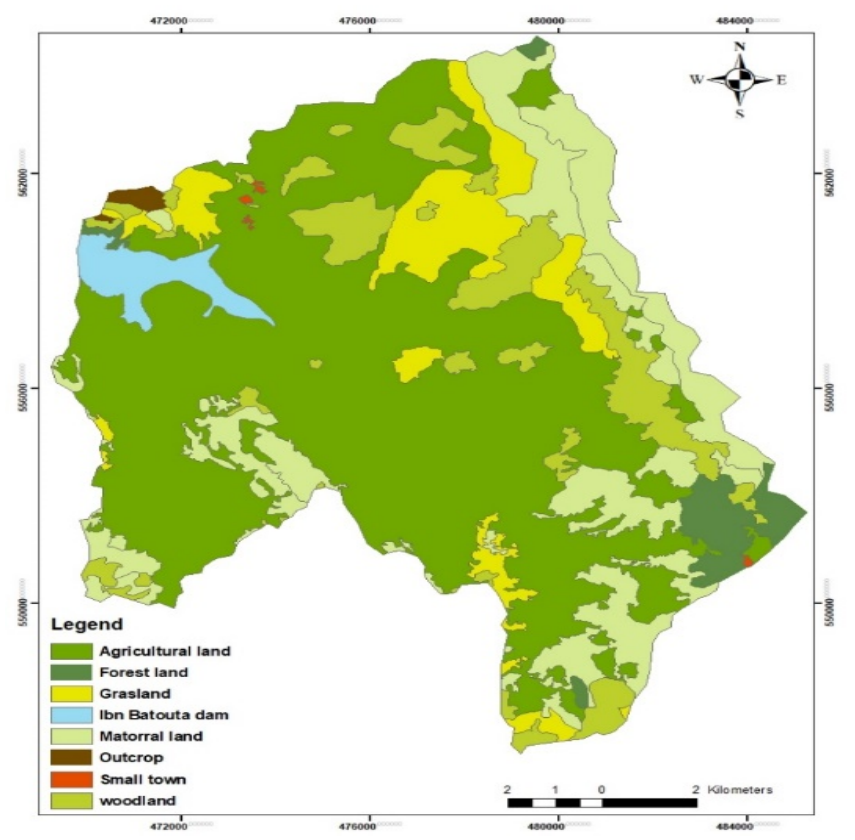

Figure 4. Map of land cover and use

\section{Precipitation Characteristics}

The annual precipitation in Tleta watershed is about $786 \mathrm{~mm}$ (1983 2011), of which the majority (86\%) falls between October and March (ABHL, 2013). The most erosive season is autumn, with a maximum erosivity value of $322.1 \mathrm{MJ} \mathrm{mm} / \mathrm{ha} / \mathrm{hr}$ in October (Choukri et al., 2016). The rainfall database consisted of a long series of data recorded in stations within the watershed. The maximum annual rainfall recorded is $1800 \mathrm{~mm}(1995-2009)$ at Béni Harchan station, while the minimum annual rainfall (about $400 \mathrm{~mm}$ ) is observed in 1995 at Ibn Batouta, Kalaya, and Beni Harchan stations (Azaaj, 2015).

Table 2. Coordinates of measurement stations

\begin{tabular}{|c|c|c|c|}
\hline Nom & Latitude N & Longitude W & Measurement frequency \\
\hline Béni Harchane & 35,531 & $-5,720$ & Daily \\
\hline Ibn Battouta & 35,645 & $-5,733$ & Daily \\
\hline Kalaya & 35,673 & $-5,747$ & Daily \\
\hline
\end{tabular}

\section{AGWA-K2 Simulation and Calibration}

The K2 calibration is performed for the rain event in Table 3 based on the available data. During this step, the hydraulic conductivity (Ks) was adjusted (Refsgaard, 1997; Semmens et al., 2008). AGWA contains the entire database used to provide initial estimates for K2 parameters based on topography, soil, and land cover (Woolhiser et al., 1990). The input parameters are derived directly from these database using optimized look-up tables, provided with the 
tool to facilitate parameterization and calibration of K2 (Semmens et al., 2008). After a series of simulations, the model calibration for the calibrated parameters does not deviate too much from the initial parameters. The main goal of this task is to test the robustness of the AGWA-K2 coupling to simulate runoff in Tleta watershed. For this purpose, the simulations were first carried out with calibration in order to assess the scope of the selected initial parameters. This will make it possible to verify the opportunity of using KINEROS2 model coupled with experimental and/or estimated physical parameters to predict floods and lands likely to be degraded following rainy events. The second goal is to estimate the dam siltation expected to be generated while analyzing the different outputs of the model.

Table 3. Characteristics of selected floods for K2 simulations

\begin{tabular}{|c|c|c|c|c|c|}
\hline & Rainfall & $\mathbf{V}\left(\mathbf{m}^{3}\right)$ & I (mm/h) & Rain (mm) & Qs (Kg/s) \\
\hline \multirow{3}{*}{ 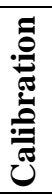 } & 24/12/2009 & 30249 & 33 & 24 & 527 \\
\hline & 03/02/1998 & 840672 & 29 & 29 & 7982 \\
\hline & $28 / 03 / 2004$ & 113184 & 29 & 21 & 281 \\
\hline \multirow{4}{*}{ } & $22 / 04 / 2003$ & 254880 & 27 & 27 & 1544 \\
\hline & $30 / 11 / 2012$ & 375839 & 33 & 28 & 3101 \\
\hline & 06/01/2010 & 2533247 & 36 & 37 & 29519 \\
\hline & 19/11/1999 & 3455 & 5 & 15 & 9.91 \\
\hline
\end{tabular}

\section{Validation and Model Performance Criteria}

Several criteria are involved in evaluating the performance of hydrological forecasts. To evaluate the model, there are two statistical criteria and these are NSE and $\mathrm{R}^{2}$. Nash-Sutcliffe efficiency (NSE), used as a major objective function in the calibration and validation processes, demonstrated the model's ability to explain data variability. It determines the relative variance of observed data compared to the variance of measured data (Nash \& Sutcliffe, 1970). The coefficient of determination $\left(\mathrm{R}^{2}\right)$ criteria was additionally used for the evaluation. These performance indices were calculated based on (equations 1 and 2).

$$
N S E=1-\frac{\sum i\left(Q_{m, i}-Q_{s}\right) i^{2}}{\sum i\left(Q_{m, i}-Q_{m}\right) i^{2}}(1) \quad R^{2}=\frac{\left[\sum i\left(Q_{m, i}-\bar{Q}_{m}\right)\left(Q_{s, i}-\bar{Q}_{s}\right)\right]^{2}}{\sum i\left(Q_{m, i}-\bar{Q}_{m}\right)^{2} \sum i\left(Q_{s, i}-\bar{Q}_{s}\right)^{2}}(2)
$$

Where $\mathrm{Q}$ is a variable, $\mathrm{m}$ and $\mathrm{s}$ are the measured and simulated variables, $\mathrm{i}$ is the measured or simulated data. 


\section{Results and Discussions \\ KINEROS2 Output Data Infiltration}

Infiltration occurs from precipitation depending on the variation of Ks due to topography and the presence of rocks as well as vegetation in the watershed. In K2, the conceptual model of hydrology represents the soil in one or two layers, the upper layer being of arbitrary depth (Smith \& Goodrich, 2000). The soil infiltration rate is calculated for each soil layer using a series of equations (Smith et al., 1995).
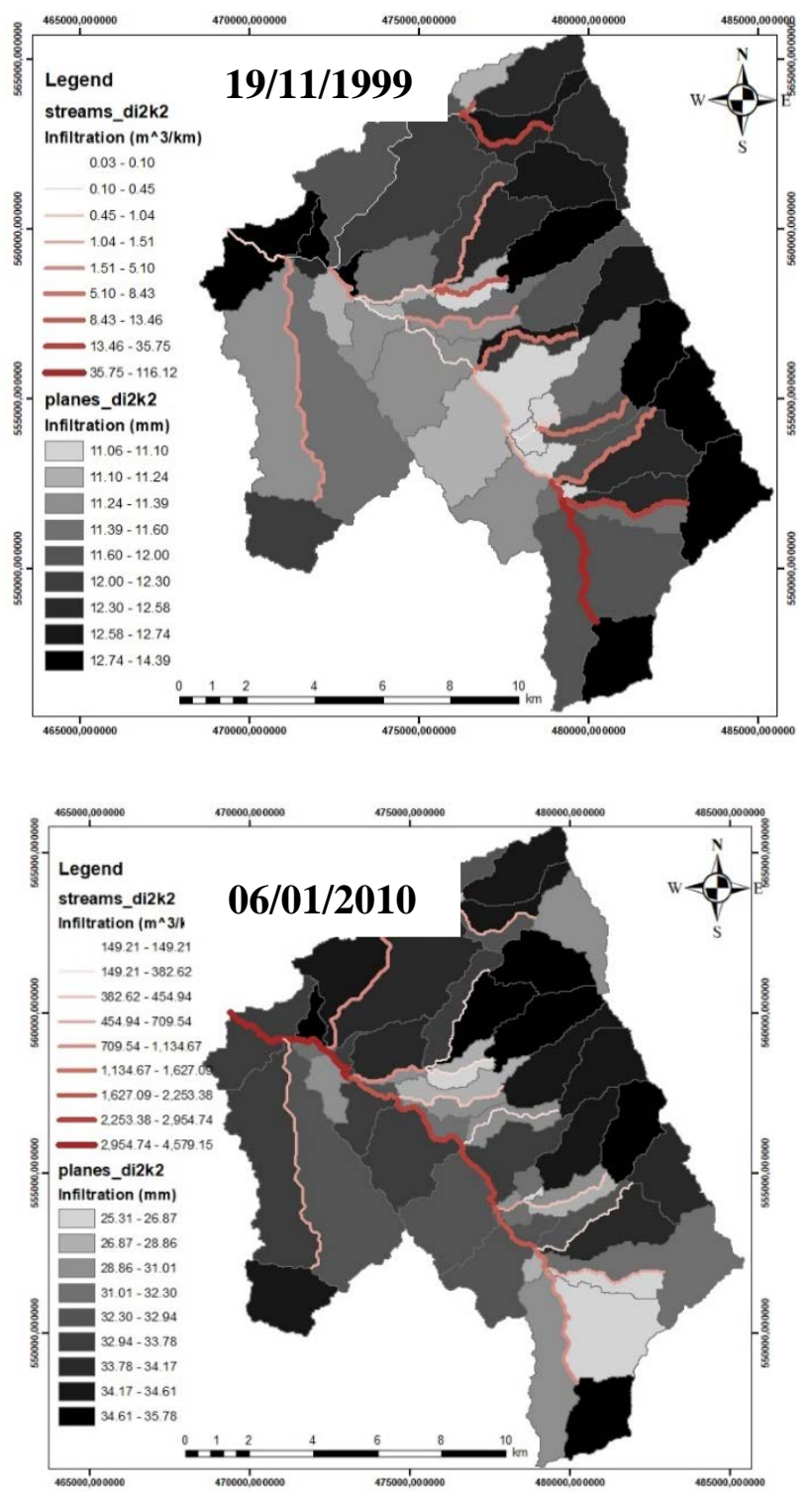

Figure 5. Infiltration rates in streams and plans 


\section{Surface Runoff}

Surface runoff occurs when the rate of precipitation exceeds the rate of infiltration (Hortonian flow) and is influenced by a combination of factors that include precipitation intensity, vegetation openness, soil type, moisture, and permeability. The K2 model relies on the Soil Conservation Service (SCS) method to calculate runoff (Semmens et al., 2008). The results showed that a significant amount of surface runoff occurs in plans near the dam as shown in Figure 6, where infiltration is low.

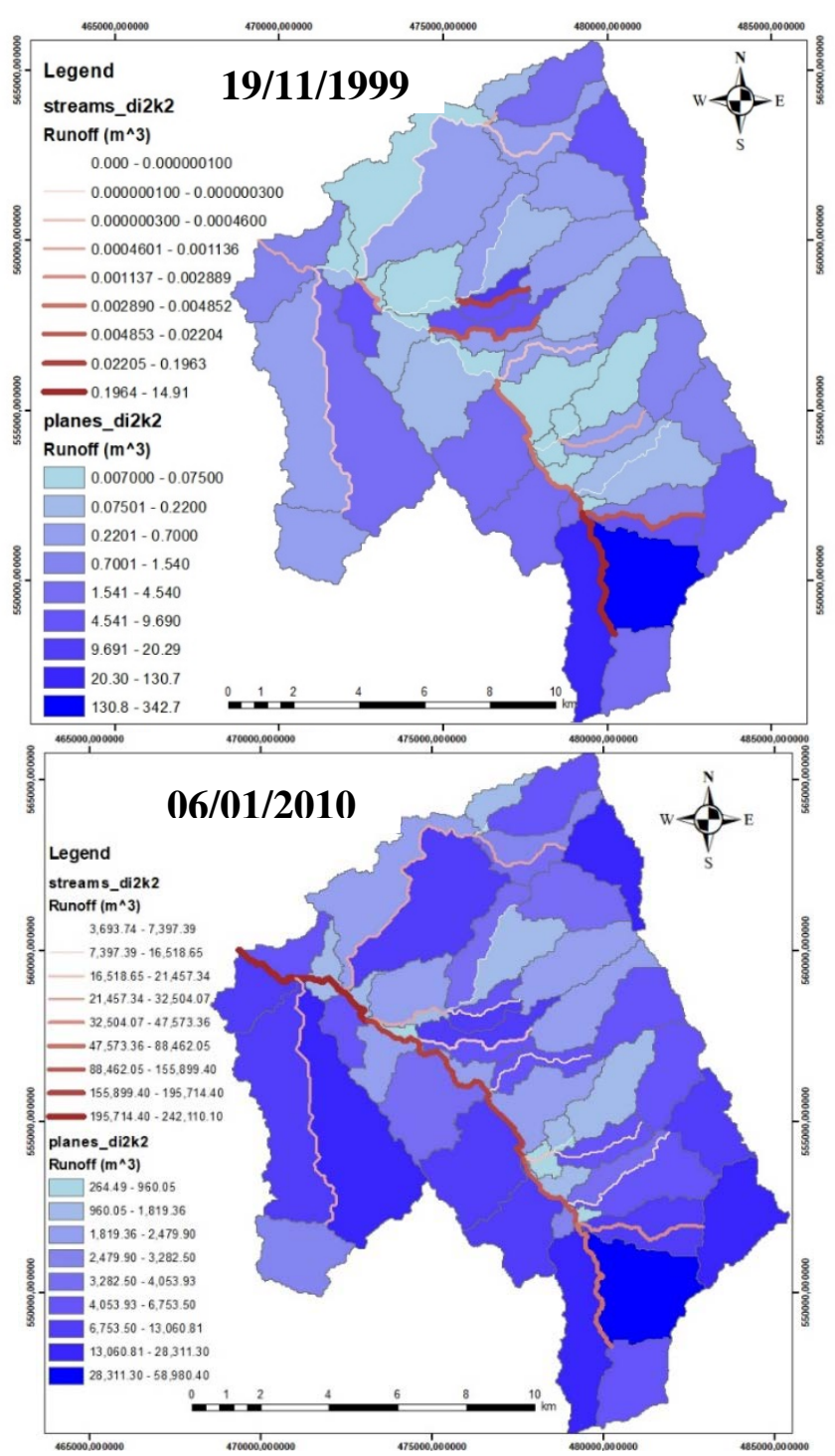

Figure 6. Runoff in streams and plans 


\section{Sediment Yield}

Intense precipitation increases the amount of sediment transported in the basin. The presence of vegetation cover and its density influences the amount of energy available to move water and sediment. The transport of solids is solved by K2 using finite difference techniques (Smith et al., 1995). The increase in sediment transport along the channels is due to soil texture. A high sediment value is shown at some plans, as shown in Figure 7.
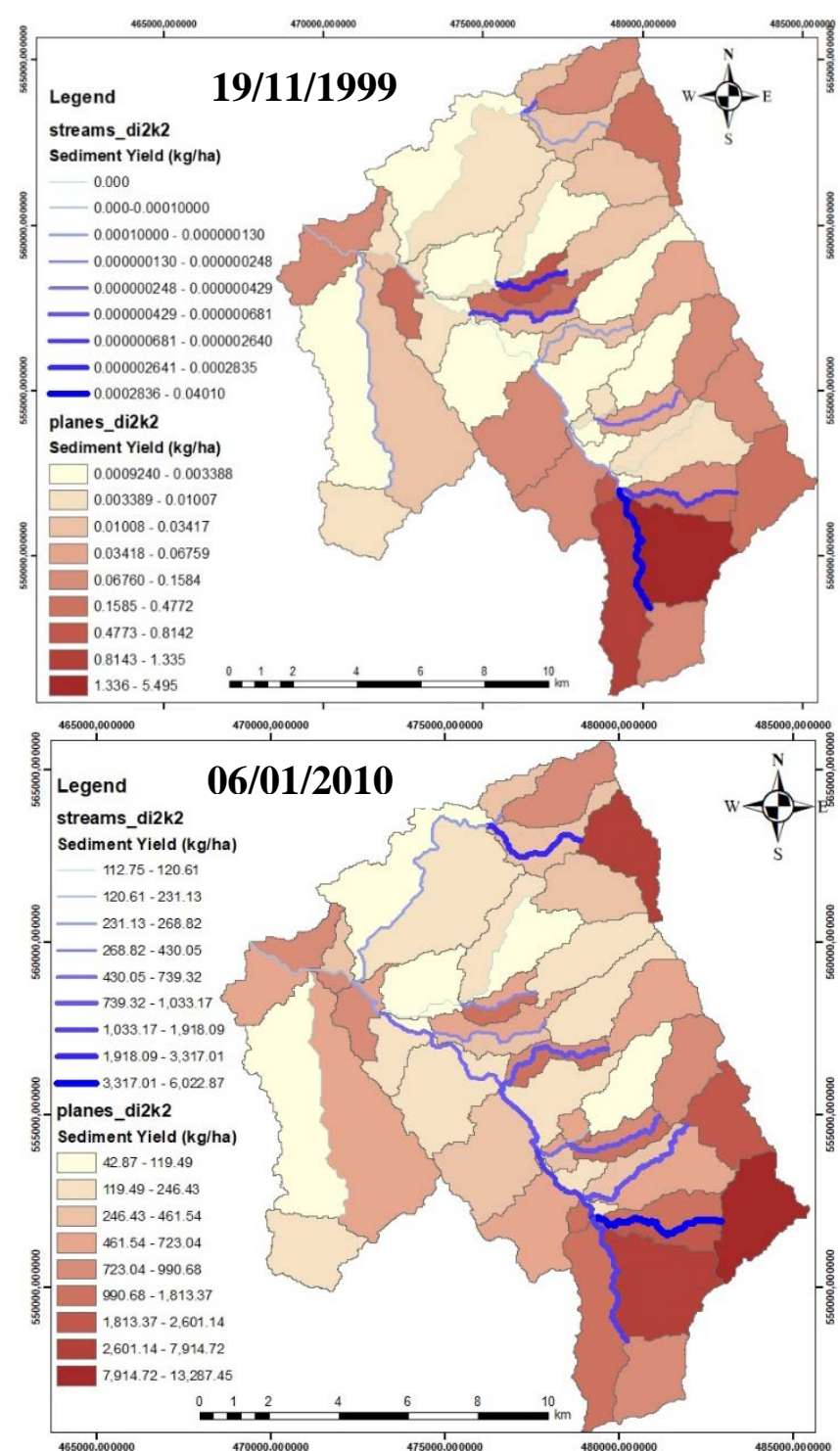

Figure 7. Sediment yield in streams and plans

As shown in the previous figures, surface runoff occurs when the rate of precipitation exceeds the rate of infiltration and it is influenced by a set of 
factors as previously mentioned. The Tleta watershed is very erosive and therefore more productive of sediments. It is also noteworthy to mention that the channels have a higher potential for sediment transport to the reservoir site.

\section{Model Validation}

The allocation of hydrodynamic parameters for each element of the watershed was crucial and was achieved by coupling K2 with AGWA GIS interface. This integration facilitated the achievement of hydrological simulations for the Tleta watershed. By using DEM, a vegetation map, a soil map and precipitation data, combined with databases integrated into AGWA from literature and experiments (Rawls et al., 1982; Smith et al., 1995), the tool was able to generate parameter files, which represent the basic input data for the K2 model. On the whole, the results achieved are promising as they are closer to the reality on the watershed. The calibration of the physical parameters of K2, the verification and validation of forecasts, gave satisfactory results. The Nash-Sutcliffe Simulation (NSE) and the coefficient of determination $\left(\mathrm{R}^{2}\right)$ were greater than 0.5 , when comparing observed and simulated data. A slight reduction in agreement for runoff was observed $\left(\mathrm{R}^{2}=\right.$ 0.99 and NSE $=0.71)$ with a better accuracy for sediments yield $\left(\mathrm{R}^{2}=0.99\right.$ and NSE $=0.72)$ during calibration. The model appeared very steady with $\left(\mathrm{R}^{2}=\right.$ 0.99 and NSE $=0.98)$ for runoff and $\left(\mathrm{R}^{2}=0.99\right.$ and NSE $\left.=0.97\right)$ for sediments yield during the validation phase.

Table 4. Simulations of selected rainy episodes

\begin{tabular}{|c|c|c|c|c|c|c|c|c|c|c|}
\hline \multirow{2}{*}{\multicolumn{2}{|c|}{ Events }} & \multirow{2}{*}{$\begin{array}{c}\text { Rain } \\
\text { mm }\end{array}$} & \multicolumn{2}{|c|}{ Runoff $\left(\mathbf{m}^{3}\right)$} & \multirow{2}{*}{ NSE } & \multirow{2}{*}{$\mathbf{R}^{2}$} & \multicolumn{2}{|c|}{ Sediments (kg/s) } & \multirow{2}{*}{ NSE } & \multirow{2}{*}{$\mathbf{R}^{2}$} \\
\hline & & & Observed & Simulated & & & Observed & Simulated & & \\
\hline \multirow{3}{*}{ 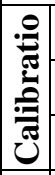 } & $24 / 12 / 2009$ & 24 & 30249 & 41492 & \multirow{3}{*}{0.71} & \multirow{3}{*}{0.99} & 527 & 407 & \multirow{3}{*}{0.72} & \multirow{3}{*}{0.99} \\
\hline & $03 / 02 / 1998$ & 29 & 840672 & 511961 & & & 7982 & 4734 & & \\
\hline & $28 / 03 / 2004$ & 21 & 113184 & 52524 & & & 281 & 695 & & \\
\hline \multirow{4}{*}{ 司 } & $22 / 04 / 2003$ & 27 & 254880 & 300984 & \multirow{4}{*}{0.98} & \multirow{4}{*}{0.99} & 1544 & 2785 & \multirow{4}{*}{0.97} & \multirow{4}{*}{0.99} \\
\hline & $30 / 11 / 2012$ & 28 & 389664 & 477692 & & & 3291 & 5130 & & \\
\hline & $06 / 01 / 2010$ & 37 & 2533247 & 2275739 & & & 29519 & 26003 & & \\
\hline & $19 / 11 / 1999$ & 15 & 3455 & 586 & & & 9.91 & 15 & & \\
\hline
\end{tabular}



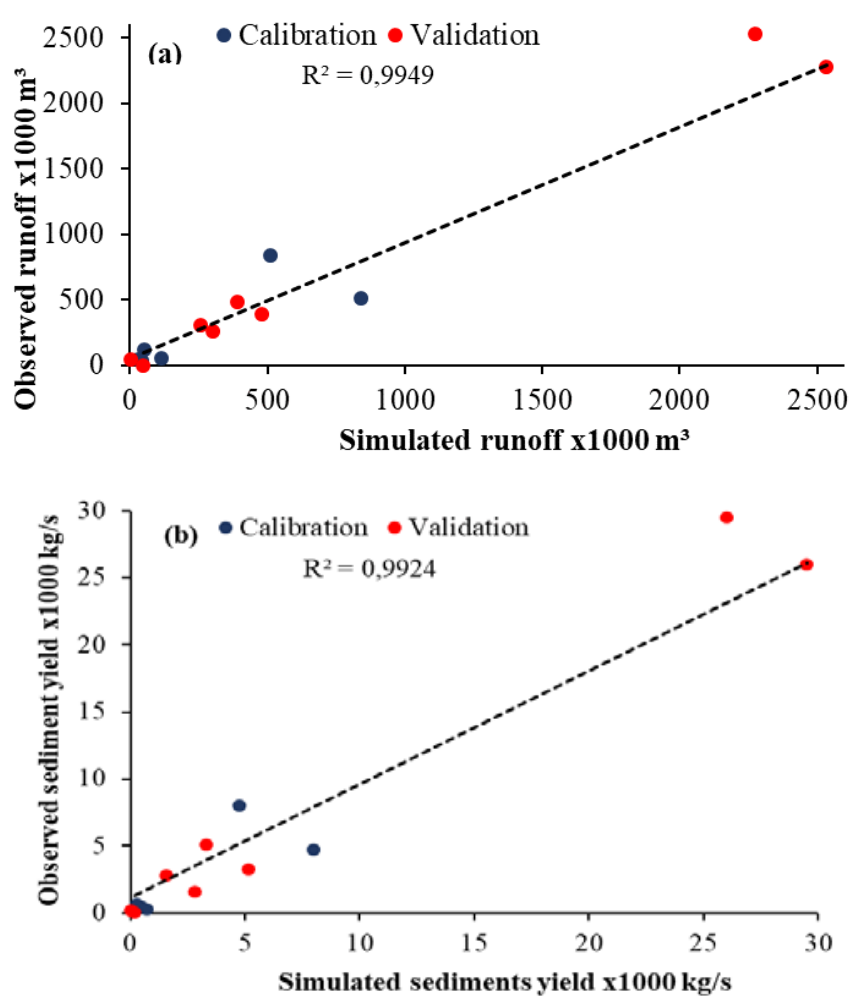

Figure 7. Observed vs simulated runoff (a) and sediment yields (b) in Tleta watershed

The results showed that there is a good agreement between observed and simulated values for the selected floods and the parameters adopted. This is even when K2 seems to slightly underestimate runoff and overestimate sometimes the sediments yields, which is due to errors during model calibration. Therefore, the implementation of KINEROS2 model coupled with AGWA offers the possibility to simulate variations in runoff and sediments yield as a function of precipitation amount, soil and land cover in Tleta watershed.

\section{Conclusions}

The AGWA is a promising tool for assessing, quantifying, and identifying the effects of water erosion at the Tleta watershed level. Overall, water modeling with calibration remains good. Indeed, the results achieved are close to the reality on ground, which makes AGWA-K2 a good coupling for integrated soil and water resource management combined with sustainable exploitation in Tleta watershed, as well as neighboring watersheds of similar biophysical settings. The approach followed has proven to be effective in predicting runoff and sediment yield in the study area based on readily available data. The implementation of KINEROS2 model offers the possibility 
to simulate runoff variations as well as sediment transport and infiltration rate as a function of precipitation amount, land cover, and soil types. The results indicate also that the integration of local data into AGWA is adequate for hydrological modeling of Tleta watershed and for assessing its vulnerability to water erosion. Future analysis should be oriented towards a comparison of flows by varying future scenarios of land cover and climate. The aim is to highlight the effect of global changes on the watershed's behavior with regard to water erosion for final validation of the model in order to identify areas at risk and deduce the lifespan of the dam to help in decision-making on possible developments.

\section{Acknowledgments}

The authors would like to express their appreciation to Hassan II Academy of Science and Technology for their funding support to GISEC project, as well as the Hassan II Institute of Agronomy and Veterinary Medicine for their multifaceted financial support during the different phases of this study.

\section{References:}

1. ABHL (2013). Etude d'actualisation du plan directeur d'aménagement intégré des ressources en eau des bassins Loukkos, Tangérois et côtiers Méditerranéens. Mission 1, Sous Mission 1.1 : Analyse et synthèse des connaissances actuelles dans le domaine des ressources en eau, Ressources en eau superficielles, ABHL, Tétouan, Maroc, 186.

2. Afef, M. (2014). Simulation des averses au niveau du bassin versant Ghézala par le modèle KINEROS2. Mémoire de Master Recherche en Science de la Terre - Université de Tunis el Manar Département de Géologie, Tunis, 149.

3. Al-Qurashi, A., Mclntyre, N., Wheater, H., \& Unkrich, C. (2008). Application of the KINEROS2 rainfall-rainoff model to an arid catchment in Oman. Journal of Hydrology, 355, 91-105

4. ALMIRA Project. Bassin versant de Tleta hppt://www.almiraproject.org/fr/sites/bassin-versant-de-tleta.

5. Augusto, G. S., Marques, D. S., \& Alves, N. I. (2002). Numerical modeling for surface rundoff and sediment yield coupled to GIS.

6. Azaaj, S. (2015). Diagnostic approfondi des pratiques paysannes de gestion des ressources naturelles dans le bassin versant Tleta, Tangerois Memoire de 3ème cycle: Ecole nationale forestiere d'ingenieurs de sale.

7. Bissiri, M., Othman, F., \& Sholichin, M. (2004). Dternination of runoff value using KINEROS model (Case stady in Sumpil catchment, Indonesia). ICCBT2008 . 
8. Canfield, H.E., \& Goodrich, D.C. (2005). Suggested Changes to AGWA to Account for Fire (V 2.1). USDA-ARS Southwest Watershed Research Center Tucson, Az. 85719.

9. Canfield, H.E., \& Goodrich, D.C. (2006). The impact of parameter lumping and geometric simplification in modelling runoff and erosion in the shrublands of southeast Arizona. Hydrological Processes,, 20(1), 17-35.

10. Chikhaoui, M., \& Naimi, M. (2011). Dégradation des sols dans le Rif marocain. Revue : Homme, Terre et Eaux, 149/150, 56-60.

11. Choukri, F., Chikhaoui, M., Naimi, M., Raclot, D., Pepin, Y., \& Lafia, K. (2016). Impact Du Changement Climatique Sur L'évolution De L'érosivité Des Pluies Dans Le Rif Occidental (Nord Du Maroc). European Scientific Journal November, 12(32).

12. Ezzine, H., Naimi, M., \& Zhim, S. (2011). Développement et couplage d'un sigweb-sol au modèle impelero pour le diagnostic et l'évaluation de l'érosion hydrique à l'echelle parcellaire dans le bassin versant de tleta. HTE N¹49/150.

13. Goodrich, D.C., Burns, I.S., Unkrich, C.L., Semmens, D.J., Guertin, D.P., Hernandez, M., Yatheendradas, S., Kennedy, J.R., \& Levick, L.R. (2012). Kineros2/agwa: Model use,calibration, and validation. the Soil \& Water Division of ASABE.

14. Goodrich, D.C., Sheppard, S., Barlow, J., Korgaonkar, Y., Guertin, P., Unkrich, C., \& Burns, S. (2011). The Automated Geospatial Watershed Assessment (AGWA) Tool for Rapid Post-Fire Watershed Assessments. AGWA Overview presentation: NERL Eco Modeling Mtg._Las Vegas, March 2011.

15. Goodrich, D.C., UnKrich, C.L., Smith, R.E., Guertin, D.P., Hernandez, M., Burns, I.S., Massart, J.E., Levick, L., Miller, S.N., Semmens, D.J., \& Kepner, W.G. (2011). The AGWA-KINEROS2 suite of modeling tools. Watershedmanagement 2010.ASCE2011:, 1294-1305.

16. Goodrich, D.C., Unkrich, C.L., Smith, R.E., \& Woolhiser, D.A. (2002). KINEROS2 - A distributed kinematic runoff and erosion model. in Proceeding of the Second Federal Interagency Hydrologic Modeling Conference, 12.

17. Hammouda, N. (2010). Evolution de l'occupation des sols et de l'érosion dans le bassinTleta (Rif occidental, Maroc). Mémoire de troisième cycle pour l'obtention du diplôme d'Ingénieur d'Etat en Agronomie Option : Science du Sol.

18. Helmlinger, K.R., Kumar, P., \& Foufoula-Georgiou, E. (1993). On the use of digital elevation model data for Hortonian and fractal analyses of channel networks. Available at: 
http://www.ce.umn.edu/ foufoula/papers/efg_048.pdf.

Water Resources Research, 29(8), 2599-2614.

19. Heusch, B. (1973). Estimation et contrôle de l'érosion hydraulique. C.R. Soc. Sci. Nat. Phy. Maroc,, 37, 41-54.

20. Inypsa, M. (1987). Projet Intégré de développement Agricole de Tanger-Tétouan, Secteur de Tétouan : Etude des sols au 1/100.000 (Edition au 1/50.000). S.A. et Direction Provinciale de l'Agriculture de Tétouan,.

21. Jaoued, M., Gueddari, M., \& Saadaoui, M. (2005). Modélisation de l'érosion hydrique dans le bassin versant de l'oued M'Khachbia (NordOuest de la Tunisie). Geo-Eco-Trop, 10.

22. Kalin, L., Govindaraju, R.S., \& Hantush, M.M. (2003). Effect of geomorphologic resolution on modeling of runoff hydrograph and sedimentograph over small watersheds. Journal of Hydrology, 276(14), 89-111.

23. Kepner, W.G., Semmens, D.J., Basset, S.D., Mouat, D.A., \& Goodrich, D.C. (2004). Scenario analysis for the San Pedro River, analyzing hydrological consequences for a future environment. . Environmental Modeling and Assessment, 94, 115-127.

24. Kepner, W.G., Semmens, D.J., Hernandez, M., \& Goodrich, D.C. (2008). Evaluating hydrological response to forecasted land- use change: Scenario testing with the Automated Geospatial Watershed Assessment(AGWA) tool. The third interagency conference on research in the watersheds, Este's Park, 8-1, 77-82.

25. Laetitia, G. (2016). Modélisation de l'évolution paradoxale de l'hydrologie sahélienne Application au bassin d'Agoufou (Mali). doctorat de l'Université Toulouse III Paul Sabatier (UT3 Paul Sabatier). 226.

26. Lahlou, A. (1994). Envasement des barrages au Maroc. Eds WALADA,Collection Sciences et Techniques,Casablanca,, 120.

27. Lajili, G. L. (2004). Utilisation du modèle KINEROS pour la simulation des hydrogrammes et des turbidigrammes en zone semiaride tunisienne. Revue des sciences de l'eau, 17(2), 227-244.

28. Lammadalena, N. (2010). Changements climatique et ressources en eau dans la région méditerranéenne. La lettre de veille de CIHEAM,, $12,1-4$.

29. Lane, L.J., Woolhiser, D.A., \& Yevjevich, V. (1975). Influence of simplifications in watershed geometry in simulation of surface runoff. Hydrology paper,, 81, 80.

30. Levick, L.R., Semmens, D.J., Guertin, D.P., Burns, I.S., Scott, S.N., Unkrich, C.L., \& Goodrich, D.C. (2009). Adding Global Soils Data to the Automated Geospatial Watershed Assessment Tool (AGWA). 
Proc. 2nd SAHRA (Sustainability of Semi-Arid and Riparian Areas), Univ. of Arizona, International. Symposium on Transboundary Water Manage., Nov. 16-19, 2004, Tucson,AZ.

31. Mansouri, T., Albergel, J., \& Seguis, L. (2001). Modélisation hydrologique spatialisée de petits bassins versants en contexte semiaride Méditerranéen. . In Hydrologie des Régions Méditerranéennes :Séminaire International, Montpellier(FRA), 225236.

32. Miller, S., Kepner W.G., Mehaffey, M.H., Hernandez, H., Miller, R.C., Goodrich, D.C., Devonald, K.K., Heggem, D.T., \& Miller, W.P. (2002). Integrating landscape assessment and hydrologic modeling for land coverchange analysis. American Water Resources Association, 38 ( 4 ), 915 - 929.

33. Miller, S., Semmens, D.J., Goodrich, D.C., Hernandez, M., Miller, R.C., Kepner, W.G., \& Guertin, D.P. (2007). The Automated Geospatial Watershed Tool. Environmental modeling \& software, 22, 365-377.

34. Miller, S., Semmens, D.J., \& Miller, R.C. (2002). GIS-based hydrologic modeling: the Automated Geospatial Watershed Assessment tool. Proceed ings of the Second Federal Interagency Hydrologic Modeling Conference July 29-Aug 1, Las Vegas, NV.

35. Morrison, J., Madramootoo, C., \& Chikhaoui, M. (2013). Modeling the influence of tile drainage flow and tile spacing on phosphorus losses from two agricultural fields in southern Québec. Water Quality Research Journal of Canada, 48, 279-293.

36. Nash, J. E., \& Sutcliffe, J. V. (1970). River flow forecasting through conceptual models: part I. A discussion of principles. J.Hydrol, 10(3), 282-290.

37. Pepin., Y., Planchon, O., Naimi, M., \& Chikaoui, M. (2012). Accroissement du risque d'érosion dû à la pluie au Nord du Maroc 11èmes Journées d'Etude des Sols, Versailles

38. Rawls, W.J., Brakensiek, D.L., \& Saxtonn., K.E. (1982). Estimation of Soil Water Properties. Transactions of the ASAE, 25(5), 1316-1320.

39. Refsgaard, J.C. (1997). Parameterisation, calibration and validation of distriduted hydrological models. Journal of Hydrology,, 198, 1-4.

40. Sabir, M., Barthès, B., \& Roose, E. (2004). Recherche d'indicateurs des risques de ruissellement et d'érosion sur les principaux sols des montagnes méditerranéennes du Rif occidental (Maroc). . Science et changements planétaires /Sécheresse, 15(1), 105-110.

41. Sabir, M., Hérivaux, C., Guillot, F., \& Bouaziz, A. (2019). Dynamique agraire et dynamique paysagères dans le bassin versant du Tleta, Rif Occidental (Maroc). Rev. Mar. Sci. Agron. Vét., 7(2), 323-332. 
42. Semmens, D. J., Goodrich, D.C., Unkrich, C.L., Smith, R.E., Woolhiser, D.A., \& Miller, S.N. (2008). KINEROS2 and the AGWA Modeling Framework. https://www.tucson.ars.ag.gov/unit/Publications/PDFfiles/2013.pdf.

43. Smith, R.E., Goodrich, D.C., Woolhiser, D.A., \& Unkrich, C. L. (1995). KINEROS - A kinematic runoff and erosion model. chapter 20. Computer Models of Watershed Hydrology, (Ed. by Singh, V. J.) Water Resour. Pub., highlands Ranch, Colo, 697-732.

44. Smith, R.E., \& Goodrich, D.C. (2000). Model for rainfall excess patterns on randomly heterogeneous areas. J. Hydrol. Eng, 5(4), 355362.

45. Thieken, A.H., Lücke, A., Diekkrüger, B., \& Richter, O. (1999). Scaling input data by GIS for hydrological modelling. Hydrological Processes, 13(4), 611-630.

46. Woolhiser, D.A., Hanson, C.L., \& Kuhlman, A.R. (1970). Overland flow on rangeland watersheds. . J. of Hydrology (New Zealand), 9(2), 336-356.

47. Woolhiser, D.A., Smith, R.E., \& Goodrich, D.C. (1990). KINEROS, a kinematic Runoff and Erosion Model. Documentation and User Manual. U.S. Department of Agriculture, Agricultural Research Service, 77, 133. 